\title{
Improved survival in channel catfish fed mannanoligosaccharides in an extruded diet
}

\author{
Brian C. Peterson ${ }^{1^{*}}$, Natha J. Booth ${ }^{1}$, Frederic T. Barrows ${ }^{2}$, Bruce B. Manning ${ }^{3}$ \\ ${ }^{1}$ USDA/ARS Catfish Genetics Research Unit, Thad Cochran National Warmwater Aquaculture Center, Stoneville, USA; \\ ${ }^{*}$ Corresponding Author: brian.peterson@ars.usda.gov \\ ${ }^{2}$ USDA/ARS Hagerman Fish Culture Experiment Station, Hagerman, USA \\ ${ }^{3}$ Thad Cochran National Warmwater Aquaculture Center, Mississippi State University, Stoneville, USA
}

Received 19 January 2012; revised 23 February 2012; accepted 8 March 2012

\begin{abstract}
The high temperature and pressure achieved during cooking extrusion has been shown to affect nutrient availability. To determine the effects of extrusion temperature on the efficacy of mannanoligosaccharide (Bio-Mos ${ }^{\circledR}$ ) in channel catfish, 4 experimental diets were fed for 9 wks and then challenged with Edwardsiella ictaluri bacterium. Catfish $(9.9 \pm 0.4 \mathrm{~g})$ were randomly assigned to the following treatments: Low-None (low temperature process without additive); HighNone (high temperature process without additive); Low-Bio (low temperature process with 4 g/kg diet Bio-Mos ${ }^{\circledR}$ ); High-Bio (high temperature process with $4 \mathrm{~g} / \mathrm{kg}$ diet Bio-Mos $\left.{ }^{\circledR}\right)$. Although specific growth rate and food conversion ratio were similar among treatments $(P>0.10)$, survival after $E$. ictaluri challenge was highest $(P<$ 0.01) for the fish fed Low-Bio. Increasing the extrusion temperature of the Bio-Mos ${ }^{\circledR}$-laden feed resulted in survival numbers similar to diets without Bio-Mos ${ }^{\circledR}$. Extruding catfish diets supplemented with Bio-Mos ${ }^{\circledR}$ at lower temperatures may provide another strategy to control enteric septicemia of catfish.
\end{abstract}

Keywords: Catfish; Mannanoligosaccharides; Growth; Disease

\section{INTRODUCTION}

Bacterial diseases such as enteric septicemia of catfish (ESC), caused by the bacterium Edwardsiella ictaluri, impose a major constraint to channel catfish (Ictalurus punctatus) production. Methods currently used to control this disease include antibiotic therapy, vaccination, and restricted feeding. Another method that has received attention is the addition of immunostimulants to the diet. The use of immunostimulants to improve disease resis- tance in many species of fish and shrimps has recently been reviewed [1].

Immunostimulants derived from a specific strain of Saccharomyces cerevisiae, (Bio-Mos ${ }^{\circledR}$; Alltech, Inc., Nicholasville, KY) which has an outer cell wall, rich in mannan oligosaccharides, has shown promise in modulating the immune response, improving feed efficiency, and promoting growth in poultry species [2-5] and fish species [6-9] but the results have been variable. For example, rainbow trout, Oncorhynchus mykiss, fed a Bio$\operatorname{Mos}^{\circledR}$ supplemented diet showed improved weight gain and food conversion ratio (FCR) compared to controls [6]. In European sea bass, Dicentrarchus labrax, dietary Bio-Mos ${ }^{\circledR}$ enhanced growth but had no effect on FCR [7]. Two channel catfish studies have shown that dietary Bio$\mathrm{Mos}^{\circledR}$ had no effect on growth or FCR $[8,10]$. Similarly, ActiveMos ${ }^{\circledR}$ had no effect on growth or FCR in juvenile giant sturgeon (Huso huso) [9]. The differences in growth performance reported among these studies are not clear but may be species related.

Immune responses to fish fed Bio-Mos ${ }^{\circledR}$ have also been variable. For example, mortality was reduced and lysozyme and complement activity were increased in rainbow trout fed Bio-Mos ${ }^{\circledR}$ [6]. In European sea bass, there was a positive correlation between lysozyme and alternative complement pathway activities in blood and inclusion levels of dietary Bio-Mos ${ }^{\circledR}$, [7]. In addition, the phagocytic index was increased with the inclusion of Bio-Mos ${ }^{\circledR}$. Contrary to these studies, Welker et al. [10] and Peterson et al. [8] found no correlation between lysozyme and survival or other immune components in channel catfish fed Bio-Mos ${ }^{\circledR}$. Peterson et al. [8] reported an increase in survival in catfish challenged with E. ictaluri, while Welker et al. [10] found no differences in catfish fed Bio-Mos ${ }^{\circledR}$. The results of the two studies are hard to interpret as the fish were fed Bio-Mos ${ }^{\circledR}$ for different lengths of time and the Welker et al. [10] study switched to control diet before challenging the fish.

Our previous study showed that the improvement in 
survival after E. ictaluri challenge was higher only in catfish fed a $36 \%$ crude protein (CP) sinking diet supplemented with Bio-Mos ${ }^{\circledR}$ and not in a $32 \% \mathrm{CP}$ diet extruded at a local feed mill at $255 \mathrm{~F}$ [8]. These results would suggest that high extrusion temperature $(255 \mathrm{~F})$ has a negative effect on the activity of Bio-Mos ${ }^{\circledR}$. However, the extrusion process has not been shown to damage or degrade Bio-Mos ${ }^{\circledR}$ activity in poultry diets.

Feeding a floating pellet is common practice in commercial catfish production. Our previous studies showed that Bio-Mos ${ }^{\circledR}$ improved survival of channel catfish challenged with E. ictaluri, only when fed a sinking diet. The objective of the current study was to determine the efficacy of feeding yeast-derived mannans in diets extruded at a lower temperature.

\section{MATERIALS AND METHODS}

\subsection{Maintenance of Fish}

Juvenile catfish (USDA103 strain) were obtained from natural pond spawns at the USDA Catfish Genetics Research Unit, Stoneville, MS, USA. Five hundred catfish $(9.9 \pm 0.4 \mathrm{~g})$ were randomly assigned to four treatments with five replicates each. An experimental diet (Table 1) was used in a 2 by 2 factorial treatment design with two extrusion temperatures with and without Bio-Mos ${ }^{\circledR}$. The four treatments were High-None $\left(127^{\circ} \mathrm{C}\right.$, no additive), Low-None $\left(99^{\circ} \mathrm{C}\right.$, no additive), High-Bio $\left(127^{\circ} \mathrm{C}\right.$, with Bio-Mos ${ }^{\circledR}$ supplemented at $4 \mathrm{~g} / \mathrm{kg}$ diet $)$, Low-Bio $\left(99^{\circ} \mathrm{C}\right.$, with Bio-Mos ${ }^{\circledR}$ supplemented at $4 \mathrm{~g} / \mathrm{kg}$ diet). These diets were manufactured in the Feeds and Nutrition Laboratory (Fish Technology Service, US fish and Wildlife Service, Bozeman, MT) using a twin-screw cooking extruder (DNDL-44, Buhler AG, Uzwil, Switzerland). The feed mash was not steam conditioned and was exposed to an average target temperature in the barrels of either 99 or $127^{\circ} \mathrm{C}$ (Table 2). The barrels were equipped with a steam jacket which was active during extrusion of the high temperature treatments and off during the production of the low temperature treatments. Feeding rate of mash into the extruder (1212 rpm), main drive speed
$(52 \%)$, and moisture added in the barrel (4.65 gph) were held constant for all diets. The $2.0 \mathrm{~mm}$ pellets were then dried in a pulse-bed drier (Buhler AG, Uzwil, Switzerland) for approximately $22 \mathrm{~min}$ to achieve a discharge temperature of $104^{\circ} \mathrm{C}$, followed by a 10 min cooling period.

The fish were stocked into $76 \mathrm{~L}$ tanks (25 fish/tank) and allowed to acclimate for 10 days. During the acclimation period, the fish were fed their respective control diets (Low-None and High-None). After the acclimation period, the fish were anesthetized with $0.1 \mathrm{~g} \cdot \mathrm{L}^{-1}$ tricaine methanesulfonate (MS-222; Western Chemical Inc., Ferndale, WA) and group weighed to the nearest $0.1 \mathrm{~g}$. The fish were fed the four diets once per day to apparent satiation. Fish were maintained in $26.8^{\circ} \mathrm{C} \pm 0.3^{\circ} \mathrm{C}$ flowthrough well water and a $14 \mathrm{~L}: 10 \mathrm{D} \cdot \mathrm{h}$ photoperiod. Water quality $(\mathrm{pH} \sim 8.4$ and dissolved oxygen levels $>5.0$ $\mathrm{mg} / \mathrm{L})$ and flow rates $(3.8 \mathrm{~L} / \mathrm{min})$ were similar between tanks. The fish were fed the experimental diets for 9 wks and the amount of feed provided was recorded weekly. At the end of the 9-wk growth study, the fish were

Table 1. Composition of base diet for experimental feeds processed at different temperatures with and without Bio-Mos ${ }^{\circledR}$.

\begin{tabular}{cc}
\hline Ingredient & $\mathrm{g} / 100 \mathrm{~g}$ \\
\hline Soybean meal $^{\mathrm{a}}$ & 52.30 \\
${\text { Corn, whole } \text { ground }^{\mathrm{a}}}^{\mathrm{b}}$ & 31.25 \\
Menhaden fishmeal $^{\mathrm{b}}$ & 12.50 \\
Menhaden fish oil $^{\mathrm{b}}$ & 2.00 \\
Dicalcium phosphate $^{\mathrm{a}}$ & 0.75 \\
Vitamin Premix \#30 $^{\mathrm{c}}$ & 1.00 \\
Stay-C & 0.10 \\
Trace Min. Premix & 0.10 \\
\hline
\end{tabular}

${ }^{\mathrm{a}}$ Silver Cup Fish Feeds, Murray, UT, USA; ${ }^{\mathrm{b} O m e g a}$ Proteins, Houston, TX, USA; 'Contributed per kilogram of diet: vitamin A (as retinol palmitate), $10,000 \mathrm{IU}$; vitamin $\mathrm{D}_{3}, 720 \mathrm{IU}$; vitamin E (as DL-\%-tocopheryl-acetate), $530 \mathrm{IU}$; niacin, $330 \mathrm{mg}$; calcium pantothenate, $160 \mathrm{mg}$; riboflavin, $80 \mathrm{mg}$; thiamin mononitrate, $50 \mathrm{mg}$; pyridoxine hydrochloride, $45 \mathrm{mg}$; menadione sodium bisulfate, $25 \mathrm{mg}$; folacin, $13 \mathrm{mg}$; biotin, $1 \mathrm{mg}$; vitamin $\mathrm{B}_{12}, 30 \mathrm{ug}$; ${ }^{\mathrm{d}}$ Trace mineral premix; contributed in $\mathrm{mg} / \mathrm{kg}$ of diet: zinc, 37; manganese, 10 ; iodine, 5 ; copper, 1 .

Table 2. Extrusion temperatures of experimental feeds.

\begin{tabular}{|c|c|c|c|c|}
\hline & Low-None & High-None & Low-Bio & High-Bio \\
\hline Barrel section $2,{ }^{\circ} \mathrm{C}$ & 132 & 136 & 133 & 141 \\
\hline Barrel section $3,{ }^{\circ} \mathrm{C}$ & 116 & 133 & 123 & 134 \\
\hline Barrel section $4,{ }^{\circ} \mathrm{C}$ & 110 & 127 & 112 & 133 \\
\hline Barrel section $5,{ }^{\circ} \mathrm{C}$ & 67 & 124 & 64 & 127 \\
\hline Barrel section $6,{ }^{\circ} \mathrm{C}$ & 56 & 121 & 42 & 125 \\
\hline Die head, ${ }^{\circ} \mathrm{C}$ & 109 & 115 & 108 & 111 \\
\hline Average extruder temperature, ${ }^{\circ} \mathrm{C}$ & 93 & 126 & 97 & 128 \\
\hline Die pressure, PSI & 235 & 280 & 245 & 285 \\
\hline
\end{tabular}


weighed as previously described.

One mortality in the High-None treatment was recorded. The fish was taken to the Fish Diagnostic Laboratory at the Delta Research and Extension Center, Stoneville, Mississippi, USA and the cause of death was reported as "unknown."

\subsection{Edwardsiella ictaluri Challenge}

The fish $(\mathrm{N}=25 /$ tank $)$ were challenged with E. ictaluri one day after the fish were weighed and sampled. An E. ictaluri isolate from a natural outbreak (confirmed by the Fish Diagnostic Laboratory) was used for the challenge. Fish were challenged with virulent E. ictaluri (1.9 $\times 10^{7} \mathrm{cfu} / \mathrm{mL}$; final concentration) by an in situ bath immersion for 30 minutes. Mortality was recorded daily for 21 days. The fish were fed their respective diets during the challenge. Fish were not fed one day prior to challenge nor on the day of the challenge.

Studies were conducted in accordance with the principles and procedures approved by the Institutional Animal Care and Use Committee, United States Department of Agriculture/Agriculture Research Service Catfish Genetics Research Unit.

\subsection{Statistical Analysis}

Data were subjected to a two-way ANOVA and the Fisher's protected least-significant-difference procedure with Statistical Analysis System (SAS) version 9.1 software. Tank served as the experimental unit for each variable measured. A significance level of $\mathrm{P}<0.05$ was used.

\section{RESULTS}

At the end of the 9 wk growth trial, there was no significant difference in weight gain, specific growth rate (SGR), or food conversion ratio (FCR) among treatments (Table 3) $(\mathrm{P}>0.10)$. Survival after E. ictaluri challenge was higher $(\mathrm{P}<0.01)$ in the Low-Bio $(70.0 \% \pm 4.2 \%)$ compared to the other three groups (average, 50.0\% \pm $8.2 \%$ ). In addition, there was a significant temperature $\times$ additive $\left(\right.$ Bio-Mos $\left.{ }^{\circledR}\right)$ interaction $(\mathrm{P}<0.001)$.

\section{DISCUSSION}

Results of current study show that the addition of Bio$\operatorname{Mos}^{\circledR}$ at $4 \mathrm{~g} / \mathrm{kg}$ diet to channel catfish does not improve weight gain, SGR, or FCR when fed for 9 wks. These results are similar to our previous study that also showed there were no differences in growth performance in catfish fed Bio-Mos ${ }^{\circledR}$ for 6 wks [8]. Welker et al. [10] also reported that Bio-Mos ${ }^{\circledR}$ supplementation did not affect total weight gain or FCR during a 4 wk catfish study. Improvements in growth have been reported for chickens [11], pigs [12,13], rainbow trout [6] and European sea bass [7] fed Bio-Mos ${ }^{\circledR}$.

Results from studies that have fed other products derived from $S$. cerevisiae have also been variable. For example, growth rate and feed efficiency were unaffected in juvenile red drum, Sciaenops ocellatus, fed brewers yeast [14] while growth performance was improved in hybrid striped bass, Morone chrysops female x $M$. saxatilis male, [15]. Nile tilapia (Oreochromis niloticus) fed a commercial bakers yeast had better growth performance and feed utilization as well as a resistance to Aeromonas hydrophila [16]. Atlantic salmon (Salmo salar) fed dietary supplements of the prebiotics mannanoligosaccharides, fructooligosaccharides in the form of inulin, and galactooligosaccharides had no treatment effects on feed intake or growth while feed efficiency was $5 \%$ greater in the salmon fed fructooligosaccharides [17]. Variation in results likely stem from type of yeast-derived mannans used in the study, fish species, feeding duration, and concentration of supplement.

Survival after virulent $E$. ictaluri challenge was higher in Low-Bio compared to High-Bio and the two control diets. Our previous results also showed an improvement in survival after E. ictaluri challenge in catfish fed a sinking Bio-Mos ${ }^{\circledR}$-supplemented diet for 6 weeks [8]. In that same study, an extruded Bio-Mos ${ }^{\circledR}$-supplemented diet $\left(\sim 124^{\circ} \mathrm{C}\right)$ made at a commercial feed plant was not effective at reducing mortality to E. ictaluri. In the current study, there was significant temperature $\times$ Bio-Mos ${ }^{\circledR}$ interaction, suggesting extrusion temperature had a negative effect on the addition the Bio-Mos ${ }^{\circledR}$ to the diet. It is becoming clear from our studies that the higher extrusion

Table 3. Mean $( \pm \mathrm{SD}, \mathrm{N}=5$ ) weight gain, specific growth rate (SGR), feed conversion ratio (FCR), and percent survival of channel catfish fed Bio-Mos ${ }^{\circledR}$ or Control diet extruded at high and low temperatures.

\begin{tabular}{ccccccc}
\hline Additive & Temperature & Weight Gain $(\mathrm{g} / \text { fish })^{1}$ & SGR $^{2}$ & FCR $^{3}$ & ${\text { Survival }(\%)^{4}}^{C^{\mathrm{e}}}$ \\
\hline Bio & Low & $44.4 \pm 2.8$ & $2.9 \pm 0.1$ & $1.05 \pm 0.03$ & $70.0 \pm 3.9^{\mathrm{a}}$ & 0.78 \\
Bio & High & $40.3 \pm 4.6$ & $2.7 \pm 0.2$ & $1.04 \pm 0.02$ & $50.0 \pm 4.5^{\mathrm{b}}$ & 0.79 \\
None & Low & $40.6 \pm 1.9$ & $2.6 \pm 0.1$ & $1.04 \pm 0.01$ & $45.0 \pm 3.9^{\mathrm{b}}$ & 0.72 \\
None & High & $43.3 \pm 2.7$ & $2.7 \pm 0.1$ & $1.03 \pm 0.03$ & $55.0 \pm 4.7^{\mathrm{b}}$ & 0.69 \\
\hline
\end{tabular}

${ }^{1}$ Mean initial weight was $9.9 \pm 0.4 \mathrm{~g} /$ fish. ${ }^{2}$ Specific growth rates were calculated from the formula $\left[\left(\ln \left(\mathrm{BW}_{2}\right)-\ln \left(\mathrm{BW}_{1}\right) /(\mathrm{t})\right] \times 100\right.$ where $\mathrm{BW} \mathrm{C}_{1}$ and $\mathrm{BW} \mathrm{W}_{2}$ are initial and final weights, respectively, and $\mathrm{t}$ is feeding period (days). ${ }^{3}$ Feed conversion ratios were calculated as ingested food (g)/weight gain (g). ${ }^{4}$ Survival is the percentage of fish alive 21 days after 30 -min. bath exposure to E. ictaluri. ${ }^{\mathrm{a}, \mathrm{b}}$ Within columns, values with different letters are different $(\mathrm{P}<0.01)$. 
temperature $\left(>124^{\circ} \mathrm{C}\right)$ negatively affects the efficacy of supplemented Bio-Mos ${ }^{\circledR}$ in catfish diets. The extrusion process has not been shown to damage or degrade Bio$\mathrm{Mos}^{\circledR}$ activity in poultry diets which are not made to float. There are likely differences in the temperature and moisture combination in the cooling process that may be responsible for the differences observed between supplementing Bio-Mos ${ }^{\circledR}$ to poultry versus catfish diets.

In another catfish study, Welker et al. [10] fed channel catfish Bio-Mos ${ }^{\circledR}$ a sinking pellet for 4 wks followed by a 2 wk period of control feed before E. ictaluri challenge. The fish were also fed the control diet for 21 days during the disease challenge. Welker et al. [10] did not observe any improvement in survival. It is likely that the effects of Bio-Mos ${ }^{\circledR}$ were diminished because the fish were switched to control feed 2 wks prior to challenge. Bio$\mathrm{Mos}^{\circledR}$ is intended to be fed on a continuous basis (John Sweetman, Alltech, Inc., personal communication); although short-duration feeding of immunostimulants, followed by control feeding has been shown to be an effective method of enhancing the immune system and disease resistance $[18,19]$. In commercial catfish production, withdrawing Bio-Mos ${ }^{\circledR} 2$ wks prior to disease outbreaks in catfish ponds would not be practical since it is difficult to predict when a disease will break in a pond.

Studies have demonstrated improvement in disease resistance and improvement of indicators of immune status when fish were administered Bio-Mos ${ }^{\circledR}$. In rainbow trout, mortality was reduced and lysozyme and complement activity were increased in fish fed Bio-Mos ${ }^{\circledR}$ [6]. In European sea bass, there was a positive correlation between lysozyme and alternative complement pathway activities in blood and inclusion levels of dietary Bio-Mos ${ }^{\circledR}$ [7]. In addition, the phagocytic index was increased with the inclusion of Bio-Mos ${ }^{\circledR}$ at $4 \mathrm{~g} / \mathrm{kg}$. Welker et al. [10] and Peterson et al. [8] found no differences in lysozyme levels in catfish fed Bio-Mos ${ }^{\circledR}$. Further studies must be conducted to understand the role of Bio-Mos ${ }^{\circledR}$ in modulating the immune system in fish.

While genetic gains towards developing lines of catfish that show improvement in disease resistance are slow, feeding yeast-derived mannans in the form of Bio$\operatorname{Mos}^{\circledR}$ may prove beneficial in increasing resistance to diseases such as ESC. Future research will focus on "ideal" inclusion levels of Bio-Mos ${ }^{\circledR}$ into catfish diets as well as a more in depth effort into understanding the mechanism(s) through which Bio-Mos ${ }^{\circledR}$ effects immune function.

\section{ACKNOWLEDGEMENTS}

The authors thank the assistance of Monica Wood of the USDA/ARS Catfish Genetics Research Unit for their efforts in maintaining the fish, disease challenge, and sample collection. The authors would like to thank Dr. Tyler Bramble of Alltech, Inc. for providing support for this project. Mention of trade names or commercial products is solely for the purpose of providing specific information and does not imply recommendation or endorsement by the US Department of Agriculture.

\section{REFERENCES}

[1] Dalmo, R.A. and Bogwald, J. (2008) $\beta$-glucans as conductors of immune symphonies. Fish \& Shellfish Immunology, 25, 384-396. doi:10.1016/j.fsi.2008.04.008

[2] Spring P., Wenk, C., Dawson, K.A. and Newman, K.E. (2000) The effects of dietary mannan oligosaccharides on cecal parameters and the concentrations of enteric bacteria in the ceca of Salmonella-challenged broiler chicks. Poultry Science, 79, 205-211.

[3] Iji, P.A., Saki, A.A. and Tivey, D.R. (2001) Intestinal structure and function of broiler chickens on diets supplemented with a mannan oligosaccharide. Journal of the Science and Food Agriculture, 81, 1186-1192. doi:10.1002/jsfa.925

[4] Hooge, D.M. (2004) Turkey pen trials with dietary mannan oligosaccharide: Meta-analysis, 1993-2003. International Journal of Poultry Science, 3, 179-188. doi:10.3923/ijps.2004.179.188

[5] Nollet, L., Huyghebaert, G. and Spring, P. (2007) Effect of dietary mannan oligosaccharide (Bio-Mos) on live performance of broiler chickens given an anticoccidial vaccine (paracox) followed by a mild coccidial challenge. Journal of Applied Poultry Research, 16, 397-403.

[6] Staykov, Y., Spring, P., Denev, S. and Sweetman, J. (2007) Effect of a mannan oligosaccharide on the growth performance and immune status of rainbow trout (Oncorhynchus mykiss). Aquaculture International, 15, 153-161. doi:10.1007/s10499-007-9096-Z

[7] Torrecillas, S., Makol, A., Caballero, M.J., Montero, D., Robaina, L., Real, F., Sweetman, J., Tort, L. and Izquierdo, M.S. (2007) Immune stimulation and improved infection resistance in European sea bass (Dicentrarchus labrax) fed mannan oligosaccharides. Fish \& Shellfish Immunology, 23, 969-981. doi:10.1016/j.fsi.2007.03.007

[8] Peterson, B.C., Bramble, T.C. and Manning, B.B. (2010) Effects of Bio-Mos ${ }^{\circledR}$ on growth and survival of channel catfish challenged with Edwardsiella ictaluri. Journal of the World Aquaculture Society, 41, 149-155. doi:10.1111/j.1749-7345.2009.00323.x

[9] Mansour, M.R., Akrami, R., Ghobadi, S.H., Amani Denji, K., Ezatrahimi, N. and Gharaei, A. (2011) Effect of dietary mannan oligosaccharide (MOS) on growth performance, survival, body composition, and some hematological parameters in giant sturgeon juvenile (Huso huso Linneaeus, 1754). Fish Physiology and Biochemistry (in press). doi:10.1007/s10695-011-9570-4

[10] Welker, T.L., Lim, C., Yildirim-Aksoy, M., Shelby, R. and Klesius, P.H. (2007) Immune response and resistance to stress and Edwardsiella ictaluri challenge in channel catfish, Ictalurus punctatus, fed diets containing commercial whole-cell yeast or yeast subcomponents. Journal of the World Aquaculture Society, 38, 24-35. 


$$
\text { doi:10.1111/j.1749-7345.2006.00070.x }
$$

[11] Kumprecht, I., Zobac, P., Siske, V. and Sefton, A.E. (1997) Effects of dietary mannanoligosaccharide level on liveweight and feed efficiency of broilers. Proceedings of $18^{\text {th }}$ Annual Meeting of the Southern Poultry Science Society, Atlanta, 132.

[12] Pettigrew, J.E. (2000) Bio-Mos effects on pig performance: A review. In: Jacques, K.A. and Lyons, T.P., Eds., Alltech's 16th Annual Symposium, Nottingham University Press, Nottingham, 31-45.

[13] Miguel, J.C., Rodriguez-Zas, S.L. and Pettigrew, J.E. (2002) Practical effects of Bio-Mos in nursery pig diets: A meta-analysis. In: Lyons, T.P. and Jacques, K.A., Eds., Nutritional Biotechnology in the Feed and Food Industries, from Niche Markets to Mainstream: Proceedings of Alltech's 18th Annual Symposium, Nottingham University Press, Nottingham, 425-433.

[14] Li, P., Burr, G.S., Goff, J., Whiteman, K.W., Davis, K.B., Vega, R.R., Neill, W.H. and Gatlin, D.M. (2005) A preliminary study on the effects of dietary supplementation of brewers yeast and nucleotides, singularly or in combination, on juvenile red drum (Sciaenops ocellatus). Aquaculture Research, 36, 1120-1127. doi:10.1111/j.1365-2109.2005.01333.x

[15] Li, P. and Gatlin, D.M. (2004) Dietary brewers yeast and the prebiotic Grobiotic ${ }^{\text {TM }} \mathrm{AE}$ influence growth performance, immune responses and resistance of hybrid striped bass (Morone chrysops x M. saxatilis) to Streptococcus iniae infection. Aquaculture, 231, 445-456. doi:10.1016/j.aquaculture.2003.08.021

[16] Abdel-Tawwab, M., Abdel-Rahman, A.M. and Ismael, N.E.M. (2008) Evaluation of commercial live bakers' yeast, Saccharomyces cerevisiae as a growth and immunity promoter for Fry Nile tilapia, Oreochromis niloticus (L.) challenged in situ with Aeromonas hydrophila. Aquaculture, 280, 185-189. doi:10.1016/j.aquaculture.2008.03.055

[17] Grisdale-Helland, B., Helland, S.J. and Gatlin, D.M. (2008) The effects of dietary supplementation with mannanoligosaccharide, fructooligosaccharide or galactooligosaccharide on the growth and feed utilization of Atlantic salmon (Salmo salar). Aquaculture, 283, 163-167. doi:10.1016/j.aquaculture.2008.07.012

[18] Chen, D. and Ainsworth, A.J. (1992) Glucan administration potentiates immune defense mechanisms of channel catfish, Ictalurus punctatus Rafinesque. Journal of Fish Diseases, 15, 295-304. doi:10.1111/j.1365-2761.1992.tb00667.x

[19] Bridle, A.R., Carter, C.G., Morrison, R.N. and Nowak, B.F. (2005) The effect of $\beta$-glucan administration on macrophage respiratory burst activity in Atlantic salmon, Salmo salar L., challenged with amoebic gill diseaseevidence of inherent resistance. Journal of Fish Diseases, 28, 347-356. doi:10.1111/j.1365-2761.2005.00636.x 